\title{
Lucerne establishment sequences to maximise weed control in ex-Pinus radiata L. plantations
}

\author{
D.J. MOOT, A. MILLS, A. MARSHALL and G.R. EDWARDS \\ Agriculture and Life Sciences Division, PO Box 84, Lincoln University, Canterbury \\ moot@lincoln.ac.nz
}

\begin{abstract}
Lucerne sown immediately or after different forage crop sequences was investigated as a pasture option for post forestry conversion. In this experiment superphosphate and lime were applied in March 2005 before final seedbed preparation and establishment of seven cropping sequences; 1) lucerne sown in April 2005; 2-5) greenfeed cereals (oats or triticale) sown in April 2005 followed by lucerne in October 2005 with or without a rape cover crop; 6-7) winter fallow followed by glyphosate presowing in October 2005 or March 2006. After all crop sequences, lucerne was successfully established and provided $100 \%$ control of woody and annual weeds. Average lucerne dry matter (DM) yield was $\sim 7.1 \mathrm{t} \mathrm{DM} /$ ha/yr for crops after a cereal. The last crop established also contained no woody weeds but produced $10.0 \mathrm{t}$ $\mathrm{DM} /$ ha less over the 2 years due to the long (12 month) fallow. Lucerne sown in April 2005 had to be reestablished the following October. Thus, provided soil temperatures were adequate, lucerne was successfully spring and autumn sown after plantation forests. Lucerne offers flexibility for grazing or conserving in commercial conversions where internal fences and stock water supply are often, initially, inadequate for intensive pasture management.
\end{abstract}

Keywords: Avena sativa L., Brassica napus L., forestry conversion, lucerne, Medicago sativa L., oats, rape, Trifolium repens L., triticale, white clover

\section{Introduction}

Pinus radiata L. plantations were established from the 1870 s on the Canterbury Plains in response to shortages of wood for fuel and construction, and to meet the perceived need for farm shelter in a climate with persistent strong winds. Plantings that now form part of the Selwyn Plantation Board estate date from this time. Two larger forests, Eyrewell on the north bank of the Waimakiriri River and Balmoral in the Culverden basin, were planted by the State after World War 1. Historically these forests have proved difficult to manage. They were planted in regions with a low average rainfall $(650 \pm 50$ $\mathrm{mm})$ and into low water holding capacity $(50-100 \mathrm{~mm})$ stony soils. This resulted in slow tree growth and perceptions that the quality of sawlogs from these forests was inferior to those of trees grown in other regions. Occasional catastrophic wind throw, due to strong north- west winds, and several major forest fires have also made it difficult to sustain production from the plains forests.

In contrast, rising commodity prices from alternative pastoral based outputs from dairy, beef and sheep, coupled with the increased use of centre pivot irrigation on the plains have driven a major change in land use since the 1990s. These economic changes have led land holders to reconsider the economic potential and optimum land use on the plains. Furthermore, political decisions around New Zealand's Kyoto commitment to global climate change have hastened the need to reassess and identify appropriate areas for pastoral and forest production. As such, forestry has moved to higher rainfall $(>1000 \mathrm{~mm})$ zones in the foot hills of the Southern Alps and onto Banks Peninsula while pastoral production has intensified on the easier flat land of the plains.

This land use change presents unique challenges. The scale of forest plantations means that few if any internal fences, race ways or stock water systems are in place early in the conversion process. Furthermore, land formerly used for trees is seldom improved and so is usually acidic, with low available nitrogen, due in part to a high amount of carbon from woody debris, and contains a large bank of potentially problem woody weeds (e.g. gorse and broom). Restoring soil fertility and preparing a seed bed are the first steps in pasture establishment (Condron et al. 2007). The sowing of herbaceous species is then required to provide rapid ground cover, to mitigate any possible effects of wind erosion, and provide a range of species suitable for grazing or conserving. Where irrigation is not immediately available, or unlikely to be so, pasture species suitable for dryland production are required.

Lucerne (Medicago sativa L.) provides a leguminous forage option that may be suitable in the conversion process. Traditionally lucerne has been grown on these shallow free draining soils as a high quality feed (Brown \& Moot 2004) conserved as hay or silage to be fed out in dry summer and cold winter conditions. In most cases, lucerne establishment requires lime inputs to raise the $\mathrm{pH}$ above 6.0, with superphosphate to provide required macronutrients and effective weed control to ensure successful seedling establishment. Given these precise requirements the suitability of lucerne to establish and thrive in recently converted ex-forestry soils is unknown. 
The objective of the current experiment was to determine at what stage lucerne could be used in forest conversion. Specifically, could it be established directly into a newly prepared seed bed or are prior cereal and/or brassica crops necessary? Triticale/oats and rape were used as test forage crops to provide contrasting canopy architecture that might affect weed control. During the conversion process the first sowing can be drilled after conventional cultivation. Subsequent crops or pastures are often direct drilled to avoid any further soil disturbance. The overall aim was to use these experimental results for establishment of commercial dryland pastures after forestry removal in blocks of 15 to 50 hectares.

\section{Materials and Methods}

The experiment was at the Selwyn Plantation Board Ltd experimental site for forest to pasture conversions at Darfield, Canterbury. The soil is a Lismore stony silt loam that had grown three previous rotations of Pinus radiata forests. The final rotation was harvested in 2004 and slash was windrowed and burnt. Stumps were ground and soil conditioning was conducted with a specialised mulching machine. During the final phase of soil conditioning, capital fertiliser and lime were incorporated to a depth of $0.20 \mathrm{~m}$.

The capital fertiliser application was based on initial soil tests made in February 2005 (Table 1). To address nutrient deficiencies, single superphosphate was applied at $300 \mathrm{~kg} / \mathrm{ha}$, in combination with $0.5 \mathrm{~kg}$ boron $/ \mathrm{ha}, 5 \mathrm{~kg}$ copper sulphate/ha and $10 \mathrm{t} / \mathrm{ha}$ of lime in March 2005. The subsequent soil tests in September 2005 and June 2007 quantify the changes in soil conditions from these capital fertiliser inputs. No nitrogen fertiliser was applied.

After fertiliser application, the area was harrowed and rolled twice for final seedbed preparation. A randomised complete block design experiment with seven cropping sequence treatments and five replicates was then established (Table 2). Treatment 1 (T1) was 'Grasslands Kaituna' lucerne (L) sown alone at $4.2 \mathrm{~kg} / \mathrm{ha}$ of bare, inoculated seed on 10 April 2005. At the same time four treatments (T2-T5) were established with cereal greenfeeds. Specifically, T2 and T3 were 'Hokonui' oats (O) sown on 12 April 2005 at $95 \mathrm{~kg} / \mathrm{ha}$, and T4 and T5 were 'Doubletake' triticale (T), at $100 \mathrm{~kg} / \mathrm{ha}$, on the following day. All 25 of these plots were $20 \times 50 \mathrm{~m}$ and sown with a Fiona drill and Sabre coulter in $110 \mathrm{~mm}$ drill rows. The target depth was $10 \mathrm{~mm}$ for the lucerne and $50 \mathrm{~mm}$ for the cereals. Plots for the T6 and T7 were winter fallowed (F). On 26/9/05 the entire experimental area, including the cereal and autumn sown lucerne treatments (T1-T5), were sprayed with Round-up Renew at $3 \mathrm{~L} / \mathrm{ha}(490 \mathrm{~g} / \mathrm{L}$ ai glyphosate) plus Pulse at $500 \mathrm{ml} / 100 \mathrm{~L}$. Following this on 5 October 2005 'Grasslands Kaituna' lucerne was sown at $10 \mathrm{~kg} / \mathrm{ha}$ of coated seed into half of the plots that had previously contained cereals (T2, T4) and resown into the autumn sown lucerne crop (T1), which had failed to establish. The remaining half of the former cereal plots (T3, T5) and one of the winter fallow plots (T6) were sown with 'Winfred' rape as the brassica (B) cover crop at $1.5 \mathrm{~kg} /$ ha at $30 \mathrm{~mm}$ depth. This was immediately followed by the lucerne at a depth of $10 \mathrm{~mm}$. The remaining winter fallow plots for $\mathrm{T} 7$ were also summer fallowed before a second spraying on 27 February 2006 with Round-up Transorb at $3 \mathrm{~L} / \mathrm{ha}(540 \mathrm{ml} / \mathrm{L}$ ai glyphosate $)$ and Pulse at

Table 1 Soil test results $(75 \mathrm{~mm})$ from the forestry to pasture conversion site at Darfield, Canterbury after tree removal (02/2005) and after fertiliser and lime amendments (09/2005, 06/2007).

\begin{tabular}{cccccc}
\hline & $\begin{array}{c}\mathrm{pH} \\
\left(\mathrm{H}_{2} \mathrm{O}\right)\end{array}$ & $\begin{array}{c}\text { Olsen P } \\
(\mathrm{mg} / \mathrm{kg})\end{array}$ & $\begin{array}{c}\mathrm{SO}_{4}^{-}-\mathrm{S} \\
(\mathrm{mg} / \mathrm{kg})\end{array}$ & $\begin{array}{c}\mathrm{Al}^{3+} \\
(\mathrm{meq} / 100 \mathrm{~g})\end{array}$ & $\begin{array}{c}\mathrm{C}: \mathrm{N} \text { ratio } \\
(\text { soil only) }\end{array}$ \\
\hline $02 / 2005$ & 4.6 & 12 & 8 & 2.5 & 23 \\
$09 / 2005$ & 5.9 & 21 & 12 & $<0.1$ & \\
$06 / 2007$ & 6.0 & 11 & 8 & $<0.1$ & 18 \\
\hline
\end{tabular}

Table 2 Pasture establishment sequences used after clearance of pine trees at Darfield, Canterbury. Note: (-) indicates lucerne was established previously.

\begin{tabular}{ccccc}
\hline Treatment & $\begin{array}{c}\text { Pasture sequence } \\
\text { Acronym }\end{array}$ & Autumn 2005 & Spring 2005 & Autumn 2006 \\
\hline T1 & LLL & Lucerne & Lucerne & $(-)$ \\
T2 & OLL & Oats & Lucerne & $(-)$ \\
T3 & OBL & Oats & Brassica+Lucerne & $(-)$ \\
T4 & TLL & Triticale & Lucerne & $(-)$ \\
T5 & TBL & Triticale & Brassica+Lucerne & $(-)$ \\
T6 & FLL & Fallow & Lucerne & $(-)$ \\
T7 & FFL & Fallow & Fallow & Lucerne \\
\hline
\end{tabular}


Figure 1 Monthly (a) rainfall (mm) and (b) mean air temperature ( ${ }^{\circ} \mathrm{C}$ ) in $2005(\square), 2006(\square)$ and 2007 (网) at Darfield, Canterbury. Long term (1919-2005) means $(-)$ were recorded on site.
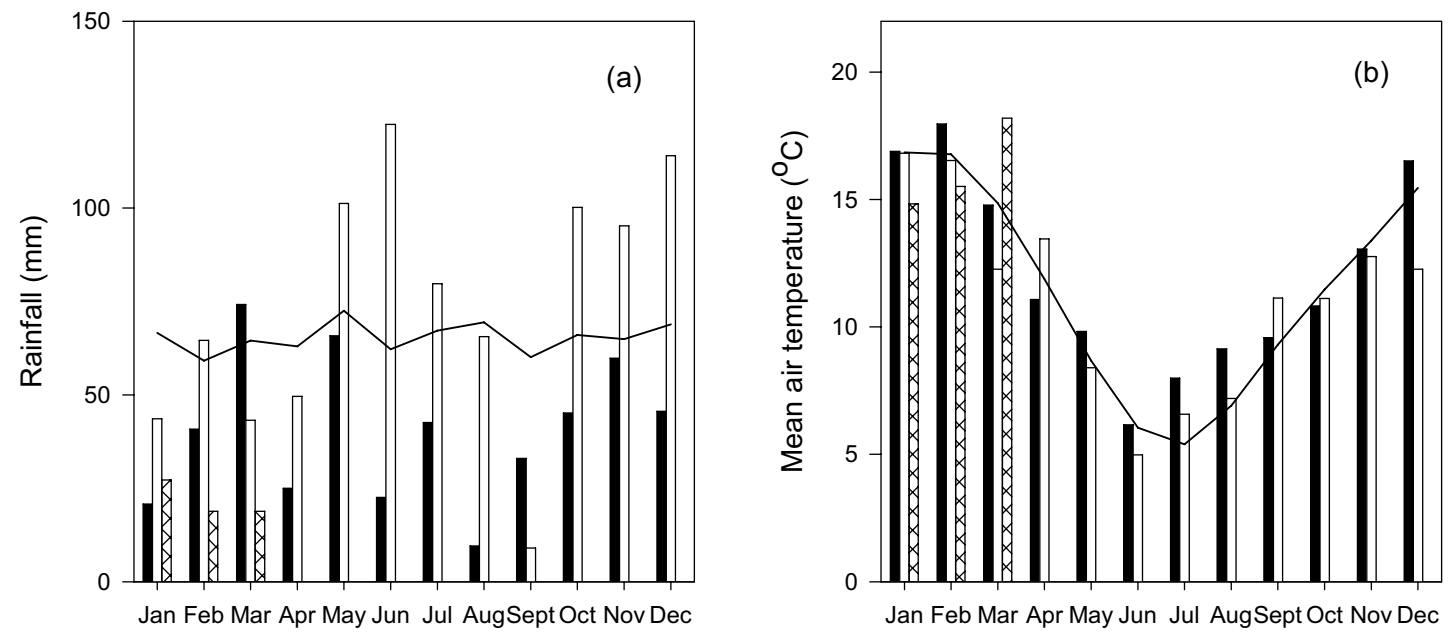

Month

Figure 2 Total lucerne yield $(\mathrm{kg} \mathrm{DM} / \mathrm{ha})$ and height $(\mathrm{cm})$ determined from rising plate meter readings. Calibrations were made on 5 May $2006(\boldsymbol{O})$, 3 October $2006(\bigcirc), 27$ November $2006(\boldsymbol{\nabla})$, 8 January $2007(\nabla)$ and 5 March $2007(\square)$. Regression forced through the origin; $D M=103 \times\left(R^{2}=0.82\right)$.

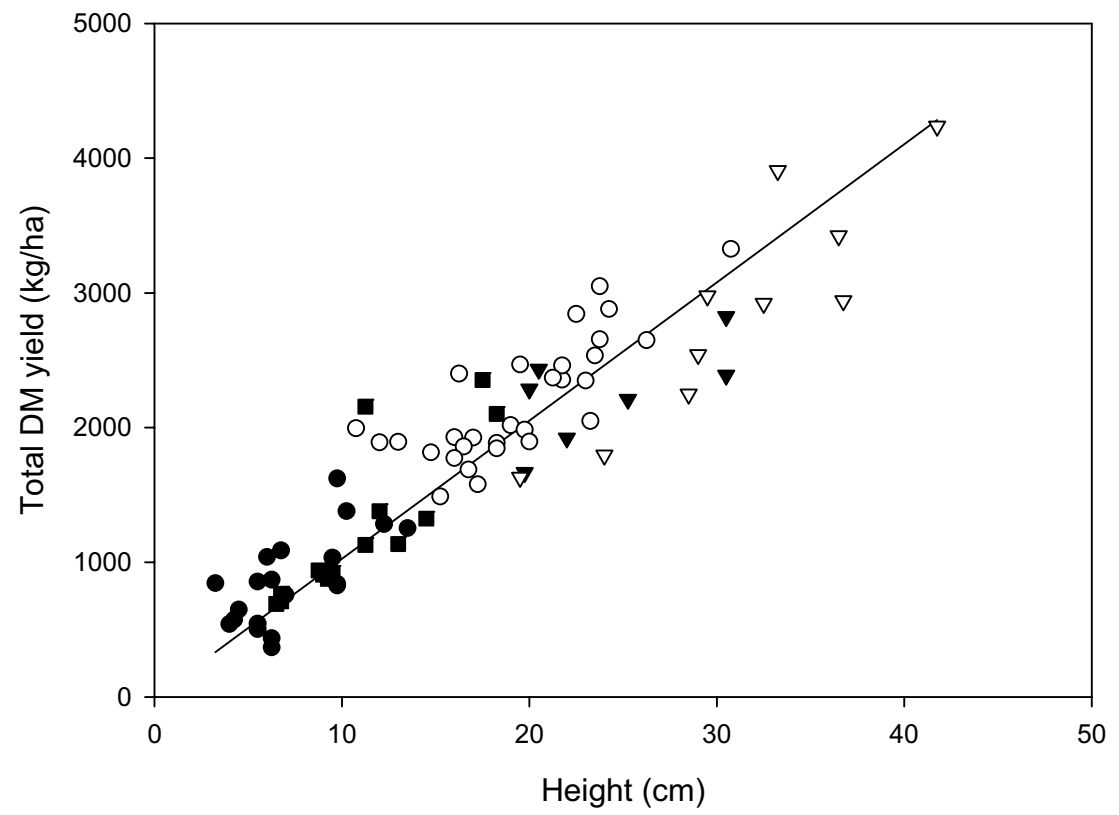

$200 \mathrm{ml} / 100 \mathrm{~L}$. Lucerne was sown into these plots on 6 March 2006 at $10 \mathrm{~kg} / \mathrm{ha}$ of coated seed with a triple disc drill to complete the FFL sequence for T7 (Table 2).

\section{Environmental conditions}

Total annual rainfall was $485 \mathrm{~mm}$ in 2005 and $888 \mathrm{~mm}$ in 2006 compared with the long term mean annual rainfall (1919-2005) of 777 mm (Fig. 1). Rainfall measured on site showed that monthly rainfall was below average throughout 2005, with the exception of March. This lack of precipitation meant lucerne and forage crop establishment was delayed until April in autumn 2005. In contrast, above average monthly rainfall in 7 of 12 months in 2006 allowed the early March establishment of the final lucerne crop (T7). Mean monthly air temperature followed long term seasonal variation and was a maximum of $18.2^{\circ} \mathrm{C}$ in March 2007 and a minimum of $5.0^{\circ} \mathrm{C}$ in June 2006. 


\section{Measurements}

The sequential nature of the establishment phase meant that not all treatments had crops or lucerne established on each measurement date. The first measurement of dry matter (DM) was for the cereals (T2-T5) on 17 August 2005 using a calibrated rising plate meter. The calibration relationship was $\mathrm{y}=96.7 \mathrm{x}\left(\mathrm{R}^{2}=0.78\right)$ for oats and $\mathrm{y}=90.9 \mathrm{x}$ $\left(\mathrm{R}^{2}=0.70\right)$ for triticale. Plots were then grazed by 600 ewe hoggets/ha on 20 August 2005. On 28 November 2005 , seedling counts were made in all treatments except $\mathrm{T} 1$ and $\mathrm{T} 7$. The number of lucerne, volunteer white clover, dicotyledonous annual weeds and gorse and broom seedlings were counted along with any rape seedlings (T3+T5) in $2 \times 0.2 \mathrm{~m}^{2}$ quadrats per plot positioned across the drill rows.

On 10 January 2006, when all pastures except T7 had been sown, DM yield and botanical composition were measured from $2 \times 0.2 \mathrm{~m}^{2}$ quadrats per plot. Prior to cutting, quadrats were also measured with the rising plate meter to create a calibration suitable for estimating DM production (Fig. 2). Plate meter readings (40/plot) were then used in conjunction with the calibration to estimate total DM production for harvests between 5 May 2006 and 4 January 2007. At each harvest, additional destructive measurements from at least one replicate were also made and added to the calibration. A final destructive harvest with botanical composition measurements was made from two replicates of all treatments on 5 March 2007.

After each sampling date all plots were grazed with $600+$ ewe hoggets for a maximum of 5 days to remove all herbage.

\section{Analysis}

Data were analysed using ANOVA in Genstat 9 as a randomized complete block experiment once all treatments were established. Least squares linear regression was calculated for the dry matter versus height calibrations. Means separation was based on a series of orthogonal contrasts that accounted for the difference in time lucerne was sown. Contrasts compared 1$)$ oats $(\mathrm{T} 2+\mathrm{T} 3)$ versus triticale $(\mathrm{T} 4+\mathrm{T} 5)$ as the initial greenfeed crop, 2) oats and triticale followed by lucerne sown either with $(\mathrm{T} 3+\mathrm{T} 5)$ or without (T2+T4) a brassica cover crop, 3) lucerne sown alone directly after a winter fallow (T6+T7) or following a

Table 3 Seedling populations (plants $/ \mathrm{m}^{2}$ ) of lucerne, volunteer white clover (VWC), greenfeed cereals, weeds and gorse measured on 28 November 2005. Acronyms for treatment sequences were presented in Table 2.

\begin{tabular}{ccccccc}
\hline Treatment & Sequence & Lucerne & VWC & Rape & Weeds & Gorse/Broom \\
\hline T2 & OLL & 123 & 7 & 0 & 26 & 6 \\
T3 & OBL & 112 & 9 & 17 & 30 & 10 \\
T4 & TLL & 143 & 17 & 0 & 18 & 8 \\
T5 & TBL & 115 & 9 & 26 & 26 & 4 \\
T6 & FLL & 125 & 10 & 0 & 33 & 4 \\
\hline SEM & & 11.8 & 4.6 & 4.8 & 5.6 & 3.3 \\
\hline
\end{tabular}

Table 4 Total dry matter (DM) yields at the end of each of seven individual rotations made between sowing and 5 March 2007. Total is the accumulated yield of the sown species for the 23 month experimental period. Note: '-' indicates no harvest.

\begin{tabular}{clcccccccc}
\hline Treatment & Sequence & $17 / 8 / 05$ & $10 / 1 / 06$ & $5 / 5 / 06$ & $3 / 10 / 06$ & $27 / 11 / 06$ & $8 / 1 / 07$ & $5 / 3 / 2007$ & Total \\
\hline T1 & LLL & - & 1894 & 497 & 1463 & 2210 & 2151 & 1043 & 8883 \\
T2 & OLL & 2396 & 2083 & 713 & 1823 & 2510 & 2366 & 1359 & 12747 \\
T3 & OBL & 2596 & 2422 & 490 & 1561 & 2420 & 2331 & 1241 & 12426 \\
T4 & TLL & 2538 & 1944 & 490 & 1635 & 2044 & 2273 & 1092 & 11397 \\
T5 & TBL & 2630 & 2140 & 414 & 1475 & 2125 & 2106 & 1091 & 11484 \\
T6 & FLL & - & 2056 & 578 & 1854 & 2633 & 2679 & 1528 & 10982 \\
T7 & FFL & - & - & - & - & - & - & 1597 & 820 \\
\cline { 2 - 9 } & SEM & 163.3 & 171.4 & 59.3 & 192.7 & 184.1 & 170.9 & 94.5 & 652.7 \\
& Contrasts (P values) & & & & & & $<0.001$ & $<0.001$ \\
& FLL v FFL & - & - & - & - & - & - & - \\
& FLL v Cereals & 0.639 & 0.447 & 0.240 & 0.096 & 0.044 & - & 0.044 \\
& Triticale v Oat & 0.233 & 0.020 & 0.103 & 0.052 & 0.362 & 0.045 & 0.041 \\
& Brassica v no brassica & 0.134 & 0.020 & 0.040 & 0.982 & 0.561 & 0.628 & 0.811 \\
& Cereals v FLL/FFL & - & - & - & - & - & 0.023 & - \\
& FFL v others & - & - & - & - & - & 0.022 & $<0.001$ \\
\hline
\end{tabular}


greenfeed crop (T2-T5) and 4) lucerne sown alone after just a spring fallow (T6) or after a spring and autumn fallow (T7).

\section{Results}

\section{Seedling counts}

The initial seedling counts on 28 November 2005 showed similar populations in all treatments (Table 3 ). Lucerne seedlings were $123 \pm 11.8 / \mathrm{m}^{2}$, and rape $22 \pm 4.0 / \mathrm{m}^{2}$ in $\mathrm{T} 3$ and $\mathrm{T} 5$ with woody weeds present in all treatments.

\section{Total dry matter (DM) yields}

The four cereal greenfeed crops all produced similar $(\mathrm{P}<0.755)$ yields of $2540 \pm 163 \mathrm{~kg} \mathrm{DM} /$ ha by 17 August 2005 (Table 4). For the rotation ending 10 January 2006, all treatments produced similar $(\mathrm{P}<0.352)$ total dry matter yields. At the second harvest, (5 May 2006) total yields were $150 \mathrm{~kg} \mathrm{DM} /$ ha lower $(\mathrm{P}<0.02)$ in the lucerne crops that had been undersown with a brassica (T3+T5) than those that were direct drilled into the cereal stubble $(\mathrm{T} 2+\mathrm{T} 4)$. By the third harvest on 3 October 2006, the total yield was still less $(\mathrm{P}<0.040)$ for lucerne previously undersown with rape than those after a cereal only. This difference was not apparent for the subsequent harvests in November 2006 and January 2007. However, at both of those harvests there was $\sim 400 \mathrm{~kg} \mathrm{DM} / \mathrm{ha}$ more lucerne from winter fallowed treatments $(\mathrm{T} 6+\mathrm{T} 7)$ compared with those after a cereal (T2-T5). Similarly in November 2006, there was an indication $(\mathrm{P}<0.052)$ that the crops that followed oats yielded more than those that followed triticale. The final destructive harvest on 5 March 2007 still showed some effect of the original sowing sequence. Higher $(\mathrm{P}<0.045)$ yields were measured from the crops established after oats $(\mathrm{T} 2+\mathrm{T} 3)$ compared with triticale (T4+T5) but there was no effect of the brassica cover crop. Analysis of the total accumulated dry matter from the sown species (lucerne + cereals and/or rape) showed the cumulative effects of the establishment sequences. Over the 23 months, the crops originally sown with oats $(\mathrm{T} 2+\mathrm{T} 3)$ yielded about $1400 \mathrm{~kg} \mathrm{DM} / \mathrm{ha}$ more than those established under triticale (T4+T5) or that had an initial winter fallow only (T6).

\section{Botanical composition}

At the first harvest on 10 January 2006 botanical composition differed among crops (Table 5). Contrasts showed reduced $(\mathrm{P}<0.013)$ lucerne yields with the inclusion of the rape cover crop (T3+T5) but this was compensated for by the rape yield which also reduced weed and white clover content in the undersown crops. The dominant weed species at the site was fathen (Chenopodium album). Broom and gorse represented $<1 \%$ of total DM yields and were not observed after each grazing. The higher $(\mathrm{P}<0.029)$ dead content in the lucerne crops that followed cereals reflects the sprayed off spring regrowth of cereals post-grazing and the rape stubble (T2-T5) compared with the crops that were fallowed.

Botanical composition on 5 May 2006 also showed yield was reduced $(\mathrm{P}<0.005)$, by $170 \mathrm{~kg} \mathrm{DM} / \mathrm{ha}$ for lucerne and $15 \mathrm{~kg} \mathrm{DM} /$ ha for weeds by the inclusion of rape which contributed $65 \mathrm{~kg} \mathrm{DM} / \mathrm{ha}$ of regrowth (data not shown). Again the lucerne yield after oats $(\mathrm{T} 2+\mathrm{T} 3)$ was $120 \mathrm{~kg} \mathrm{DM} /$ ha more $(\mathrm{P}<0.031)$ than after triticale. There was no volunteer white clover present, nor any contribution from either gorse or broom at this time.

Subsequent visual observations showed no weeds were present in any of the crops at harvests made on 3 October 2006, 27 November 2006 or 8 January 2007 so measured total DM yields (Table 4) were 100\% lucerne. Botanical composition of pastures measured on 5 March 2007 showed total weed control in all treatments except $(\mathrm{P}<0.001)$ the final crop established (T7). These plots contained $54 \%$ lucerne, $30 \%$ dicotyledonous weeds

Table 5 Dry matter (DM) yields of pasture components ( $\mathrm{kg} \mathrm{DM} / \mathrm{ha}$ ) which included lucerne, volunteer white clover (VWC), rape, dicotyledonous weeds, which includes broom and gorse, on 10 January 2006. Treatment acronyms are presented in Table 2.

\begin{tabular}{|c|c|c|c|c|c|c|}
\hline Treatment & Sequence & Lucerne & VWC & Rape & Weeds & Dead \\
\hline T1 & LLL & 1677 & 29 & 0 & 164 & 24 \\
\hline T2 & OLL & 1845 & 47 & 0 & 160 & 30 \\
\hline T3 & OBL & 1229 & 17 & 932 & 151 & 93 \\
\hline $\mathrm{T} 4$ & TLL & 1678 & 36 & 0 & 181 & 49 \\
\hline T5 & TBL & 1413 & 12 & 595 & 41 & 78 \\
\hline \multirow[t]{6}{*}{ T6 } & FLL & 1808 & 52 & 0 & 136 & 16 \\
\hline & SEM & 161.8 & 12.93 & 101.9 & 42.2 & 17.68 \\
\hline & Contrasts ( $P$ values) & & & & & \\
\hline & Brassica v no Brassica & 0.013 & 0.050 & $<0.001$ & 0.092 & 0.017 \\
\hline & FLL $\vee$ cereals & 0.156 & 0.112 & 0.008 & 0.948 & 0.029 \\
\hline & Triticale v Oats & 0.958 & 0.534 & 0.114 & 0.305 & 0.912 \\
\hline
\end{tabular}


(fathen and sheep's sorrel Rumex acetosella), 10\% white clover and $7 \%$ dead material. In contrast all other treatments (T1-T6) contained $\geq 94 \%$ lucerne, no weeds or white clover and $6 \%$ dead material at the final harvest.

\section{Discussion}

All of the lucerne crops grown after forest conversion were weed free, and comparatively high yielding after 23 months. The average annual yield of $\sim 7 \mathrm{t} \mathrm{DM} /$ ha was consistent with others reported for dryland pastures in Canterbury (White 1982; Hayman 1984). An advantage of the lucerne is that a legume monoculture is established in a soil with a high $\mathrm{C}: \mathrm{N}$ ratio (Table 1). The post-forestry conditions favour species that fix nitrogen which then reduces the need for inorganic $\mathrm{N}$ inputs required for grass based pastures (Edwards et al. 2007). The $\mathrm{pH}$ has risen to 6.0 with the lime application and this is adequate to prevent any macro or micro element deficiencies, with healthy lucerne stands actively growing throughout the 2 years. Interestingly, the Olsen $P$ value was lifted to 21 by the application of superphosphate but the most recent value of 11 indicates some of this may have complexed with the lime (calcium) and become unavailable. This requires further ongoing investigation.

In all pastures there was total weed control of the woody weeds seedlings (Table 3 ) by the end of the first year. This was probably achieved by the tall stature of the lucerne crops drawing the woody weed seedlings up in height as they competed for light. The etiolated seedlings were then observed to be palatable to the hoggets that grazed them within the inter rows and also eaten in the fallowed plots.

The complete success of lucerne within the conversion process was unexpected. Lucerne seedlings are perceived as poor competitors at establishment, because they partition a larger amount of carbon to roots in the early stages of growth than many grass and weed species. To overcome this, the cereal greenfeeds were used and expected to provide more effective initial weed control. However, the comparable success of the spring sown lucerne without a cereal (T6) indicates the cereals (T2T5) were unnecessary from a weed control perspective. The advantage of the cereals was the additional winter feed yield (Table 4 ).

The pattern of dry matter production from sown and weed species was consistent across harvests. The addition of the brassica to the spring sown lucerne (T3+T5) depressed the lucerne yield in the next two rotations but offered about the same amount of total herbage and provided greater weed control. Equally the lucerne crops established after triticale had a slightly lower yield (Table 4) than those following oats although the explanation for this is unclear.

At the final harvest, which included the first harvest from lucerne pastures established in October 2006 for T7, it was shown that there was no gorse or broom present in any of the pastures. For T7, grazing controlled the woody weeds and this may have been aided by the double spray of glyphosate in spring and autumn. However, the herbicide did not prevent a significant population of annual weeds establishing, particularly in the extended fallow plots (T7). This suggests the ground cover in T1-T6 was more effective than the fallow and double spray for overall weed control.

A potential problem of the pasture sequences used in this experiment is the inability to re-cultivate following the first establishment. Unfortunately the late sowing date of $\mathrm{T} 1$ prevented an assessment of whether lucerne could be established successfully immediately after seedbed preparation. This highlights the high base temperature of this species for germination and emergence (Moot et al. 2000). The earlier autumn rain (Fig. 1) in the second year allowed lucerne to be sown successfully in autumn as shown by T7. Based on these experimental results, commercial lucerne crops have been successfully established directly after seedbed preparation using 7 $\mathrm{kg} / \mathrm{ha}$ of bare inoculated seed and $1.5 \mathrm{~kg} / \mathrm{ha}$ of rape sown in spring.

\section{Conclusions and Practical Implications}

Lucerne provides a viable alternative to grass based pastures for establishment following the removal of forest plantations on the Canterbury plains. The infrequent hard grazing was ideal for removal of the woody weeds and of practical importance when converting large areas of land that are often poorly subdivided. The complete control of woody weeds, coupled with the flexibility lucerne offers in terms of crop management, make it a suitable species for this dryland environment. The sequence of forage crops used in the experiments had minimal impact on the botanical composition of the crops 2 years after the sowing. Overall the provision of ground cover as either a cereal or lucerne immediately after the ground has been prepared is likely to result in fewer total weeds than a winter or summer fallow. These results provide a series of options for lucerne establishment that can be fitted into the staggered timing that occurs for land preparation in the conversion process.

\section{ACKNOWLEDGEMENTS}

The Selwyn Plantation Board and Meat and Wool New Zealand Ltd for funding dryland pastures research.

\section{REFERENCES}

Brown, H.E.; Moot, D.J. 2004. Quality and quantity of chicory, lucerne and red clover production under irrigation. Proceedings of the New Zealand 
Grassland Association 66: 257-264.

Condron, L.R., Moot, D.J., Marshall, A., White, P.J.; Edwards, G.R. 2007. Pasture responses to lime and nitrogen fertilizer on land converted from pine forest to dryland pasture in Canterbury. Proceedings of the New Zealand Grassland Association 69: 111-115.

Edwards, G.R., Moot, D.J. and Marshall, A. 2007. Pasture composition and production from different cropping sequences in dryland pasture converted from Pinus radiata forest. Proceedings of the New Zealand Grassland Association 69: 87-91.
Hayman, J.M. 1984. The effect of irrigation interval and soil type on pasture and lucerne production. Proceedings of the New Zealand Grassland Association 46: 15-23.

Moot, D.J. Scott, W.R., Roy, A.M., Nicholls, A.C. 2000. Base temperature and thermal time requirements for germination and emergence of temperate pasture species. New Zealand Journal of Agricultural Research 43: 15-25.

White, J.G.H. 1982. Lucerne grazing management for the 80's. Lucerne for the 80's. Special Publication, Agronomy Society of New Zealand No. 1: 111-114. 